\title{
CTNNB1/PLAG1 Fusion Gene
}

National Cancer Institute

\section{Source}

National Cancer Institute. CTNNB1/PLAG1 Fusion Gene. NCI Thesaurus. Code C99866.

A fusion gene that results from a chromosomal translocation $\mathrm{t}(3 ; 8)(\mathrm{p} 21 ; \mathrm{q} 12)$ which fuses the promoter sequence of the CTNNB1 gene upstream of the entire PLAG1 gene. This rearrangement is associated with both aberrant expression of the zinc finger protein PLAG1 and pleomorphic adenoma of the salivary gland. 